\title{
Sudah Efektifkah Kebijakan Kawasan Tanpa Rokok di Indonesia?

\section{LATAR BELAKANG}

Era desentralisasi menjadikan pemerintah lokal memiliki wewenang untuk mencegah dampak negatif dari konsumsi tembakau. Sekitar $30 \%$ kabupaten/kota di Indonesia memiliki perda KTR, namun efektifitas kebijakan tersebut dalam menurunkan prevalensi merokok perlu diteliti. Isi kebijakan KTR hanya membatasi area merokok dan iklan rokok di wilayah yang sebagian besar sebenarnya ada di perkotaan. Bagaimana dengan kebijakan di perdesaan?

\section{TANTANGAN}

1. Isi kebijakan tiap daerah berbeda.

2. Indonesia belum meratifikasi tembakau.

3. UU tentang Pertembakauan belum disahkan.

\section{HASIL DAN PEMBELAJARAN}

Tidak ada perbedaan jumlah perokok usia remaja pada daerah dengan dan tanpa perda KTR. Contohnya di DKI Jakarta yang memiliki regulasi KTR namun kenyataannya dalam pelaksanaan tidak selalu dipatuhi. Kebijakan KTR yang ada di daerah tidak memiliki dampak pengurangan merokok pada usia remaja. Kawasan yang telah ditentukan dalam kebijakan KTR merupakan tempat-tempat yang ada di perkotaan misalnya kantor, sekolah, restoran, pasar dan rumah sakit, sedangkan di perdesaan hampir tidak ada tempat pelarangan merokok. Padahal, berdasarkan hasil Riskesdas 2013, orang yang merokok setiap hari sebagian besar (25.5\%) tinggal di daerah perdesaan.

\section{KESIMPULAN}

Kebijakan KTR di Indonesia belum efektif.

\section{SARAN}

1. Pemda yang tidak menggantungkan sumber pendapatannya dari tembakau dapat lebih tegas peraturannya. Kebijakan untuk mengurangi prevalensi perokok selain melalui KTR sebaiknya ditambah pembatasan penjualan rokok di warung-warung dan sales penjual rokok di pemukiman.

2. Larangan merokok di dalam rumah belum ada dalam perda KTR, ini dapat menjangkau perkotaan maupun perdesaan.

3. Fungsi pengawasan harus dicantumkan dengan jelas dalam perda KTR.
Keywords: Kawasan Tanpa Rokok, prevalensi merokok, pengendalian tembakau

\section{REFERENSI}

Rahajaeng, E. (2015). Pengaruh Penerapan Kawasan Tanpa Rokok erhadap Penurunan Proporsi Perokok di Provinsi DKI Jakarta, Daera Istimewa Yogyakarta dan Bali. Jurnal Ekologi Kesehatan, 14. https://doi.org/10.22435/jek.v14i3.4694.238-249

Septiono, W., N, N., \& A, K. (2018). Did local smoke free policy in donesia prevent youth from smoking? In Abstract Book 17th World

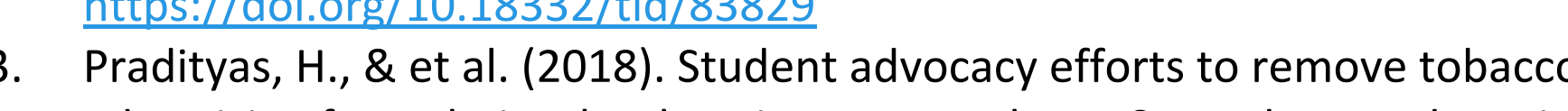
advertising from their school environment, Jakarta \& Bandung, Indonesia.

https://doi.org/10.18332/tid/84241 Najmah et al. (2015). Studi Intervensi Kawasan Tanpa Rokok pada Tingkat http://download.portalgaruda.org/article.php?article=426254\&val=7113

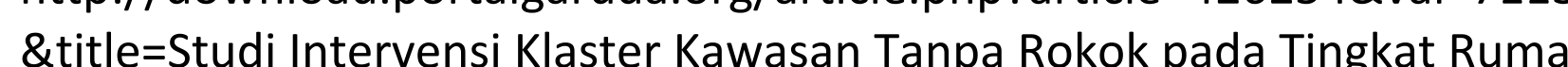
Tangga
Peraturan Gubemur DKI Jakarta Nomor 88 Tahun 2010 tentang Kawasan Peraturan Gubemu
Dilarang Merokok 